\title{
FIELD STUDY ON SOME NUTRITIONAL FACTORS CAUSING LEG PROBLEMS IN BROILERS
}

\author{
MAISA M. GHARIEB and MOHAMED K. MOURSI \\ Depts. of Pharmacology, Animal Health Research Institute- and NLQP Ismailia \\ Email: dr-mmg63@yahoo.com
}

\section{ABSTRACT}

Received at: 22/12/2013

Accepted: 26/2/2014
The present field study was carried out to investigate the relationship between some ration components and blood biochemical constituents of broiler suffering from leg problems. A total of 128 broiler chicks (2, 3, 4 and 5 weeks of age) represented 8 farms were collected, 80 clinically affected (birds showed lameness, unable to stand, bowed legs, twisted, rotated, extended laterally legs) and 48 apparently healthy. Besides 8 ration contents from the same farms. Clinical signs and postmortem were done. Ration analysis for the nutritive constituents were carried out (dry matter - ash - fat -fiber - protein - calcium phosphorous -manganese - zinc and copper). Serum samples were analyzed for calcium, phosphorous, manganese, zinc, copper, triglyceride, cholesterol, glucose and total protein. The results indicated that, a wide variation of nutrient contents was observed in the diet fed to broilers in different farms. An increase of calcium content at 2 weeks of age with wide calcium: phosphorus ratio $(3.06: 1,2.64: 1)$ in addition to marked imbalance of $\mathrm{Ca}: \mathrm{P}$ ratios of most rations $(0.84: 1,1.2: 1,1.1: 1$, 0.97:1,1.5:1 and 0.85:1). The birds reared on high dietary calcium and Low phosphorus revealed hypercalcaemia and hypophosphataemia in their sera. Feed sample contained relatively lower amount of CP (crude protein) which is $(16.63,16.98,15.59,15.15,15,14.75,14.69$ and $13.30 \%)$ for farm $F 1, F 2, F 3, F 4$, $\mathrm{F} 5, \mathrm{~F} 6, \mathrm{~F} 7$ and F8 respectively, that not matched with protein requirement at each age. Disturbance in $\mathrm{Mn}, \mathrm{Zn}$ and $\mathrm{Cu}$ contents in all farm groups. A significant differences $(\mathrm{P}<0.05)$ and $(\mathrm{P}<0.01)$ in values of the biochemical parameters within chickens of various ages were recorded. Comparison values of the biochemical parameters between groups revealed that values of calcium, phosphorous, total protein, $\mathrm{Zn}$ and $\mathrm{Cu}$ were significantly $(\mathrm{P}<0.05)$ differed from those values of corresponding biochemical parameters of apparently healthy chickens, triglyceride and cholesterol and glucose were significantly high, whilst Mn were significantly $(\mathrm{P}<0.01)$ lower in all affected chickens than apparently healthy ones. It could be concluded that, metabolic and management factors are involved in conditions of leg disorders in broilers. Deprivation in feed intake due to birds' immobility, suboptimal nutrition, feed ingredients quality, consumption and absorption moreover decrease bioavailability of some element and imbalance of others. Rations had positive effect on certain serum biochemical parameters of broiler chickens. The obtained results may be helpful in the evaluation of changes in the metabolic profile, health condition and production patterns in growing broiler chickens reared under farm conditions.

Key words: Leg problems, Broilers, Nutritional factors.

\section{INTRODUCTION}

Modern poultry farming, which has transformed from a backyard rearing activity to a dynamic industry over the past few decades, has resulted in the tremendous increase in the growth rate of muscle of poultry. However this growth isn't accompanied by skeletal development thus imparting more strain on the skeletal integrity (Robert, 2008). Leg disorders leads to high incidence of morbidity than mortality. In general, they have an incidence varying from 2 to $15 \%$, which inflict a considerable monetary loss to the producer in terms of mortality, culling on the farm and/or condemnations or downgrading at processing (Lotta, 2006).

Leg disorders and bird mobility are affected by a number of different bone, tissue and neural disorders, as well as by other factors. Deficiencies, and occasionally excesses, of certain essential nutrients play major roles in the development of several leg abnormalities in poultry, even though many leg disorders are outside the influence of nutritional factors. Among the most common leg abnormalities 
affected by nutritional practices are tibial dyschondroplasia, resulting from inadequate vascularization and ossification of the growth plate resulting in an abnormal mass of cartilage under the growth plate, causing unnatural biomechanical forces, and therefore gait alteration, additional bone abnormalities, and even fractures (Wang et al., 2013). Angular deformities of the long bones, such as varus-valgus deformities and "twisted legs" caused by a lateral or medial deviation of the distal tibia or proximal metatarsus, frequently accompanied by slippage of the gastrocnemius tendon are other common leg disorders (Riddell, 1992). Also rickets, characterized by an enlargement of the epiphyseal area and occasionally deformity of the soft, rubbery bone (Julian, 1998).

Serum biochemical parameters may provide valuable information for differential diagnosis of nutritional disorders (Quintavalla et al., 2001) and evaluation health status of birds (Krai and Suchy, 2000).

It is well established that the health and performance of birds are influenced by the nutrient and metabolites of blood that can be estimated by understanding the relationships between diet characteristics and blood biochemical parameters. The purpose of this study was, therefore, to evaluate the relationship between some ration components and blood biochemical constituents of broiler suffering from leg problems under field condition.

\section{MATERIALS and METHODS}

\section{1- Sample:}

\section{[A]- Clinical cases:}

A total of 80 clinically affected chicks (Birds showed lameness, unable to stand, bowed legs, twisted, rotated, extended laterally legs) at 2,3,4 and 5 weeks of age representing 8 broiler farms (10 birds/farm) from different localities at Ismailia province were collected, in addition to 48 apparently healthy chickens simultaneously from the same farms $(6$ birds/farm). Complete clinical signs and postmortem examination were done as well as attempts of bacteriological isolation from joint was carried out.

\section{[B] -Blood samples:}

Blood samples were collected from affected and normal birds (apparently healthy) separately in clean centrifuge tubes. Blood left to clot at room temperature for one hour, centrifuged at 3000 r.p.m for 5 minutes to separate out serum, and then the serum was kept at $-20^{\circ} \mathrm{C}$ until biochemical analysis.

\section{[C]- Rations:}

Sample of rations (1-2 kg) were collected from the same farms at the same dates whenever the birds were collected. Chemical analysis for the nutritive constituents were carried out (dry matter - ash - fat fiber - protein - calcium -phosphorous -manganese - zinc and copper) using references of Association of Official Analytical Chemists (AOAC, 1990).

\section{2- Serum biochemical analysis:}

Serum samples were analyzed for calcium, phosphorous, manganese, zinc and copper according to Perkin-Elmer using atomic absorption (model 2380, Perkin-Elmer Cooperation). Serum total protein according to (Henry, 1964). Serum cholesterol, glucose and triglyceride levels were determined by using ready-made kit from (BioMeriux -France) by Auto analyzer Hitachi 912.

3- Statistical analysis: data were analyzed using SPSS 18.0 software.

\section{RESULTS}

The clinical examination of affected chicks showed characteristic bowing or bending of the legs. The birds are reluctant to move and when forced to walk have a stiff gait. Other birds walked on the posterior surface of the hock which becomes swollen and bruised, leading to skin penetration of tibia, or clinically manifests as deformation and lameness, which later may be associated with bone fractures (Fig.1). Some birds manifested by slipped tendon which characterized by retarded growth of long bones, widening of the tibiometatarsal joint, twisting or bending of the distal end of tibia and the proximal end of metatarsus and finally, slipping of the gastrocnemius muscle tendon from its condyles. Other showed an enlargement of the epiphyseal area and occasionally deformity of the soft, rubbery bone and beak (Fig.2). In some cases, the tibia is twisted extended laterally (Fig.3). It was uni or bilateral (Fig. 4).

Postmortem finding showed persistence of cartilage as a white plug just below the growth plate in the tibia of a broiler chicken suffered from tibial dyschondroplasia (TD) (Fig. 5), The bone is not only bent but can easily fracture causing severe lameness in affected chickens. Bacteriological examinations were negative from joint of the affected birds.

Table (1) showed the result of analysis of commercial rations used in broiler farms, It was noticed that an increase of calcium content at 2 weeks of age with wide calcium: phosphorus ratio (3.06:1, 2.64:1) in addition to marked imbalance of $\mathrm{Ca}: \mathrm{P}$ ratios of most groups $(0.84: 1,1.2: 1,1.1: 1$, $0.97: 1,1.5: 1$ and $0.85: 1)$.

The Phosphorous content was high in ration of one farm at 3,4 and 5 wks. of age and low at 2 wk of age. Feed sample contained relatively lower amount of crude protein (CP) which is $(16.63,16.98,15.59,15.15,15,14.75,14.69 \quad$ and $13.30 \%$ ) for F1,F2,F3,F4,F5,F6,F7 and F8 respectively, that not matched with protein 
requirement at each age. Disturbance in $\mathrm{Mn}, \mathrm{Zn}$ and $\mathrm{Cu}$ contents in all farm groups.

Table (2) showed levels of serum calcium, phosphorus, manganese, zinc and copper at 2,3,4 and 5 weeks of ages of apparently healthy and leg affected broiler chicks. The serum calcium level was significantly high $(\mathrm{P} \leq 0.05)$ in the 2 wks. of age than other groups and in affected than normal birds, while manganese significantly lowered $(\mathrm{P} \leq 0.01)$ and zinc $(\mathrm{P} \leq 0.05)$ and $(\mathrm{P} \leq 0.01)$ but copper was significantly differed at 2 weeks of age only.
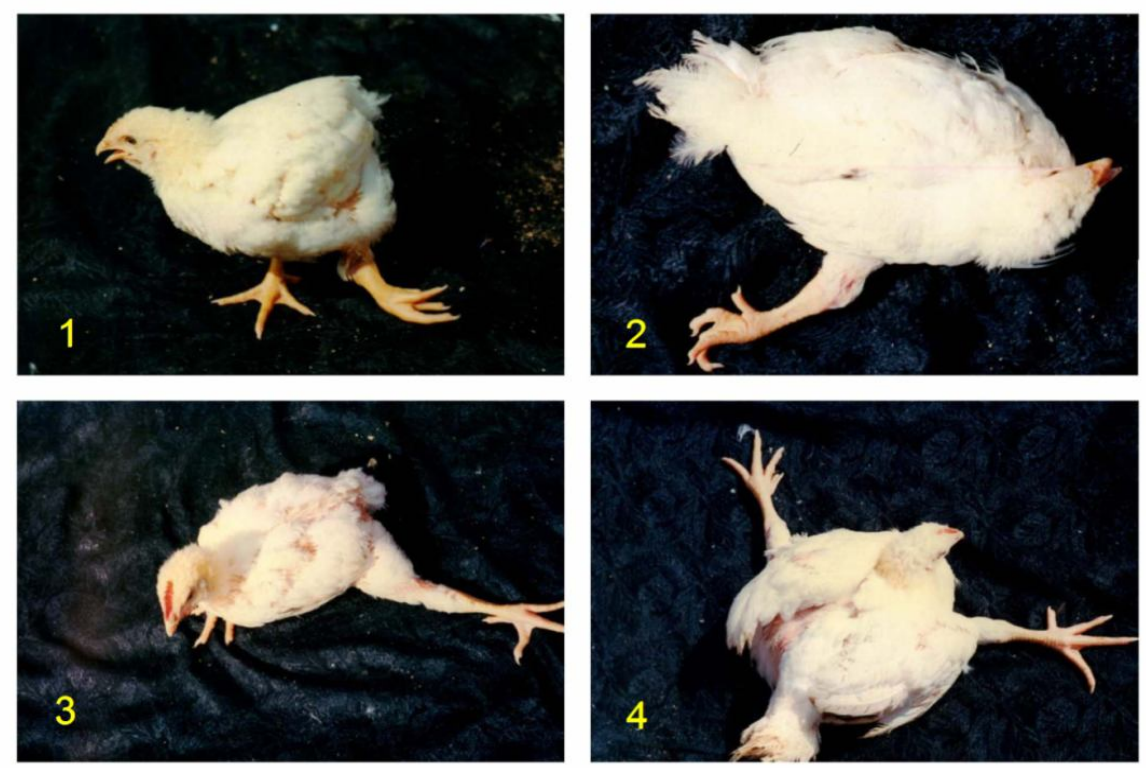

Fig (1,2,3 and 4): Showed different forms of leg affections
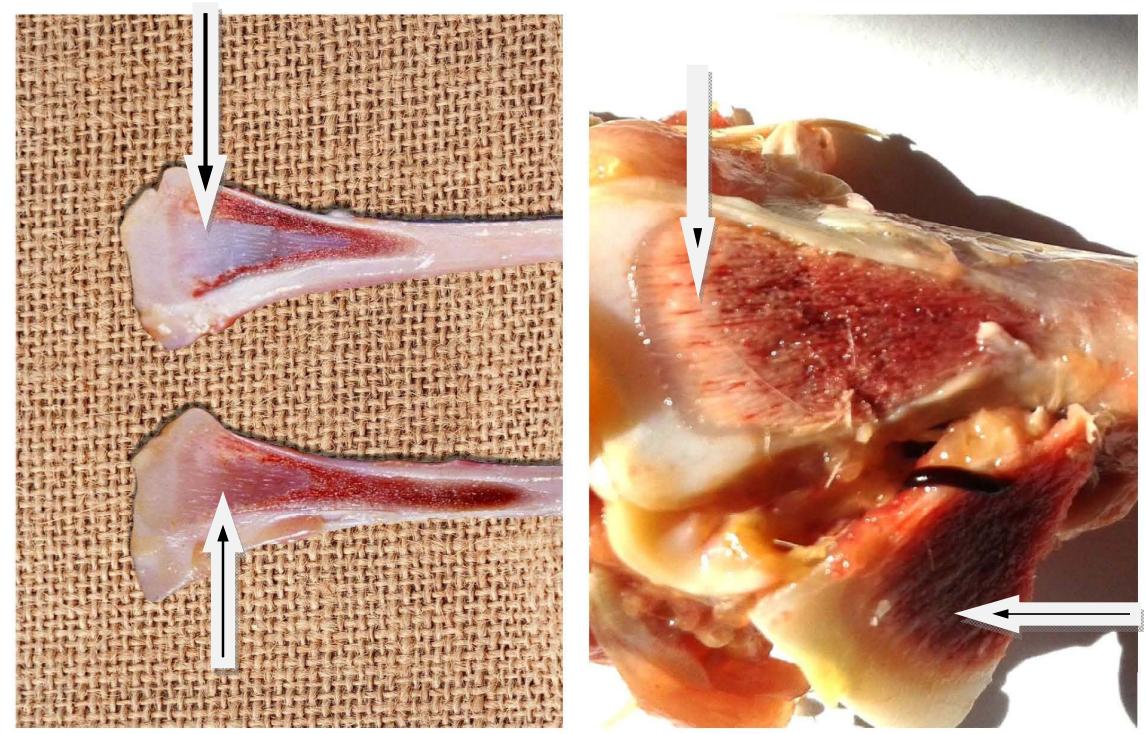

Fig. (5): Tibias of 4 weeks affected chickens showed mass of retained cartilage (as a white plug) in the proximal metaphysis with different degrees (left \& upper right) and normal tibial growth plate (lower right). 
Assiut Vet. Med. J. Vol. 60 No. 140 January 2014

Table 1: Nutritional composition of the poultry feed samples collected from different broiler farms (\% air-dry basis).

\begin{tabular}{ccccccccccccc}
\hline $\begin{array}{c}\text { Age } \\
\text { (week) }\end{array}$ & $\begin{array}{c}\text { Farm } \\
\text { No. }\end{array}$ & $\begin{array}{c}\mathrm{DM} \\
\%\end{array}$ & $\begin{array}{c}\text { Ash } \\
\%\end{array}$ & $\begin{array}{c}\text { Fat } \\
\%\end{array}$ & $\begin{array}{c}\text { Fiber } \\
\%\end{array}$ & $\begin{array}{c}\text { Protein } \\
\%\end{array}$ & $\begin{array}{c}\mathrm{Ca} \\
\%\end{array}$ & $\begin{array}{c}\mathrm{P} \\
\%\end{array}$ & $\mathrm{Ca}: \mathrm{P}$ & $\begin{array}{c}\mathrm{Mn} \\
\mathrm{ppm}\end{array}$ & $\begin{array}{c}\mathrm{Zn} \\
\mathrm{ppm}\end{array}$ & $\begin{array}{c}\mathrm{Cu} \\
\mathrm{ppm}\end{array}$ \\
\hline \multirow{3}{*}{2} & 1 & 90.73 & 8.88 & 2.78 & 2.95 & 16.63 & 1.5 & 0.49 & $3.06: 1$ & 80 & 50 & 12.50 \\
\hline & 2 & 90.07 & 7.21 & 2.81 & 2.98 & 16.98 & 1.32 & 0.50 & $2.64: 1$ & 50 & 55 & 12.30 \\
\hline \multirow{3}{*}{3} & 3 & 89.70 & 5.33 & 2.89 & 2.77 & 15.69 & 0.50 & 0.59 & $0.84: 1$ & 60 & 49 & 12.10 \\
\hline & 4 & 89.25 & 5.70 & 2.95 & 2.80 & 15.15 & 0.59 & 0.48 & $1.2: 1$ & 55 & 45 & 13.25 \\
\hline & 5 & 89.75 & 5.78 & 2.95 & 2.80 & 15.00 & 0.53 & 0.48 & $1.1: 1$ & 65 & 45 & 13.25 \\
\hline & 6 & 89.01 & 5.20 & 2.92 & 2.95 & 14.75 & 0.75 & 0.77 & $0.97: 1$ & 75 & 45 & 12.00 \\
\hline \multirow{2}{*}{5} & 7 & 89.61 & 5.80 & 2.74 & 2.91 & 14.69 & 0.70 & 0.46 & $1.5: 1$ & 70 & 50 & 12.20 \\
\hline & 8 & 88.27 & 5.03 & 1.91 & 3.31 & 13.30 & 0.60 & 0.67 & $0.85: 1$ & 100 & 50 & 12.10 \\
\hline
\end{tabular}

Table 2: Serum levels of Calcium, phosphorus, manganese, Zinc and Copper of 2,3,4 and 5 weeks of ages of apparently healthy and leg affected broiler chicks. $\mathrm{N}=10$

\begin{tabular}{|c|c|c|c|c|c|c|c|c|c|c|c|}
\hline \multirow{3}{*}{$\begin{array}{c}\text { Age } \\
\text { (week) }\end{array}$} & \multirow{3}{*}{$\begin{array}{c}\text { Farm } \\
\text { No. }\end{array}$} & \multicolumn{2}{|c|}{ Calcium mg\% } & \multicolumn{2}{|c|}{ Phosphorous mg\% } & \multicolumn{2}{|c|}{ Manganese $\mu \mathrm{g} / \mathrm{dl}$} & \multirow{2}{*}{\multicolumn{2}{|c|}{$\mathrm{Zn} \quad \mathrm{ppm}$}} & \multirow{2}{*}{\multicolumn{2}{|c|}{$\begin{array}{c}\mathrm{Cu} \\
\mathrm{Ppm}\end{array}$}} \\
\hline & & & & & & & & & & & \\
\hline & & Normal & Affected & Normal & Affected & Normal & Affected & Normal & Affected & Normal & Affected \\
\hline \multirow{4}{*}{2} & 1 & 11.05 & $13.77 *$ & 5.48 & 5.77 & 12.13 & $2.34 * *$ & 39.58 & 37.00 & 13.75 & $11.80^{*}$ \\
\hline & & \pm 0.29 & \pm 0.75 & \pm 0.16 & \pm 0.34 & \pm 0.85 & \pm 0.14 & \pm 1.43 & \pm 3.16 & \pm 1.08 & \pm 1.38 \\
\hline & 2 & 11.46 & $13.92 *$ & 5.36 & 5.22 & 12.60 & $2.53 * *$ & 41.45 & $36.20^{*}$ & 14.45 & $10.85^{*}$ \\
\hline & & \pm 0.21 & \pm 0.75 & \pm 0.16 & \pm 0.38 & \pm 0.65 & \pm 0.18 & \pm 1.49 & \pm 3.62 & \pm 1.28 & $* \pm 1.31$ \\
\hline \multirow{4}{*}{3} & 3 & 11.75 & $9.29 *$ & 6.89 & $5.24^{*}$ & 11.55 & $2.43^{* *}$ & 43.33 & $39.80^{*}$ & 9.16 & $8.20^{*}$ \\
\hline & & \pm 0.28 & \pm 0.56 & \pm 0.12 & \pm 0.28 & & \pm 0.16 & \pm 2.77 & \pm 2.68 & \pm 1.03 & \pm 0.70 \\
\hline & & 11.20 & $8.50^{*}$ & 6.48 & $5.04 *$ & 11.55 & $2.43 * *$ & 43.86 & $38.70 *$ & 9.76 & $8.10^{*}$ \\
\hline & 4 & \pm 0.38 & \pm 0.60 & \pm 0.14 & \pm 0.28 & \pm 0.30 & \pm 0.11 & \pm 2.27 & \pm 2.28 & \pm 1.05 & \pm 0.90 \\
\hline \multirow{4}{*}{4} & & 11.02 & $9.68^{*}$ & 6.87 & $4.83^{*}$ & 10.99 & $2.04 * *$ & 38.41 & $34.00 *$ & 13.08 & 12.20 \\
\hline & 5 & \pm 0.44 & \pm 0.53 & \pm 0.38 & \pm 0.33 & \pm 0.31 & \pm 0.16 & \pm 1.75 & $* \pm 2.43$ & \pm 1.11 & \pm 0.50 \\
\hline & & 10.90 & $8.66^{*}$ & 6.21 & $4.55 *$ & 10.26 & $2.15^{* *}$ & 39.45 & $34.70 *$ & 13.75 & 12.80 \\
\hline & 6 & \pm 0.49 & \pm 0.73 & \pm 0.32 & \pm 0.31 & \pm 0.31 & \pm 0.14 & \pm 1.75 & $* \pm 2.43$ & \pm 1.11 & \pm 0.50 \\
\hline \multirow{4}{*}{5} & & 11.75 & $9.59^{*}$ & 6.68 & 7.03 & 11.55 & $1.59^{* *}$ & 35.00 & $31.20 *$ & 18.75 & 18.60 \\
\hline & 7 & LV. & \pm 0.00 & \pm 0.10 & \pm 0.49 & \pm 0.50 & \pm 0.15 & $\pm 1.3 /$ & \pm 2.20 & \pm 1.85 & \pm 2.17 \\
\hline & & $\begin{array}{l}11.45 \\
+0.91\end{array}$ & $9.06^{*}$ & 6.23 & 7.26 & 11.75 & $1.59 * *$ & 36.00 & $30.40 *$ & 18.14 & 18.80 \\
\hline & 8 & \pm 0.91 & \pm 0.44 & \pm 0.11 & \pm 0.49 & \pm 0.38 & & \pm 1.37 & \pm 2.34 & \pm 1.95 & \pm 2.46 \\
\hline
\end{tabular}


Table 3: Serum levels of triglyceride, cholesterol, glucose and total protein of 2,3,4 and 5 weeks of ages of apparently healthy and leg affected broiler chicks. $\mathrm{N}=10$

\begin{tabular}{|c|c|c|c|c|c|c|c|c|c|}
\hline \multirow{2}{*}{$\begin{array}{c}\text { Age } \\
\text { (weeks) }\end{array}$} & \multirow{2}{*}{$\begin{array}{c}\text { Farm } \\
\text { No. }\end{array}$} & \multicolumn{2}{|c|}{ Cholesterol mg/dl } & \multicolumn{2}{|c|}{ Triglycerides mg/dl } & \multicolumn{2}{|c|}{ Glucose mg/dl } & \multicolumn{2}{|c|}{ Total protein $\mathrm{g} / 100 \mathrm{~m}$} \\
\hline & & Normal & Affected & Normal & Affected & Normal & Affected & Normal & Affected \\
\hline \multirow[t]{2}{*}{2} & 1 & $\begin{array}{l}143.7 \\
\pm 2.07\end{array}$ & $\begin{array}{c}142.15 \pm \\
3.58\end{array}$ & $\begin{array}{c}68.7 \\
\pm 9.43\end{array}$ & $\begin{array}{c}100.05 * * \\
\pm 2.19\end{array}$ & $\begin{array}{c}231.90 \\
\pm 5.32\end{array}$ & $\begin{array}{c}312.3 * * \\
\pm 3.41\end{array}$ & $\begin{array}{c}4.89 \\
\pm 0.33\end{array}$ & $\begin{array}{l}2.96 * \\
\pm 0.16\end{array}$ \\
\hline & 2 & $\begin{array}{c}142.44 \\
4.58 \pm\end{array}$ & $\begin{array}{l}144.35 \\
\pm 3.84\end{array}$ & $\begin{array}{c}77.0 \\
\pm 1.09\end{array}$ & $\begin{array}{c}103.24 * * \\
\pm 2.15\end{array}$ & $\begin{array}{l}210.9 \\
\pm 5.12\end{array}$ & $\begin{array}{l}377 * * \\
\pm 1.38\end{array}$ & $\begin{array}{c}5.09 \\
\pm 0.39\end{array}$ & $\begin{array}{l}2.84 * \\
\pm 0.16\end{array}$ \\
\hline \multirow[b]{2}{*}{3} & 3 & $\begin{array}{c}137.44 \\
\pm 4.8\end{array}$ & $\begin{array}{c}154.34 * * \\
\pm 2.78\end{array}$ & $\begin{array}{l}78.90 \\
\pm 2.52\end{array}$ & $\begin{array}{c}105.5^{* *} \\
\pm 5.25\end{array}$ & $\begin{array}{l}233.1 \\
\pm 9.94\end{array}$ & $\begin{array}{c}293.0 * * \\
\pm 3.68\end{array}$ & $\begin{array}{c}4.95 \\
\pm 0.33\end{array}$ & $\begin{array}{l}4.24 \\
\pm 0.18\end{array}$ \\
\hline & 4 & $\begin{array}{l}136.84 \\
\pm 4.76\end{array}$ & $\begin{array}{c}160.72 * * \\
\pm 3.95\end{array}$ & $\begin{array}{c}72.0 \\
\pm 2.82\end{array}$ & $\begin{array}{c}103.7 * * \\
\pm 9.43\end{array}$ & $\begin{array}{c}230.94 \\
4.52\end{array}$ & $\begin{array}{c}311.4 * * \\
7.12\end{array}$ & $\begin{array}{c}4.33 \\
\pm 0.38\end{array}$ & $\begin{array}{l}4.68 \\
\pm 0.15\end{array}$ \\
\hline \multirow[b]{2}{*}{4} & 5 & $\begin{array}{c}138.14 \\
\pm 5.0\end{array}$ & $\begin{array}{c}151.53 * * \\
\pm 2.36\end{array}$ & $\begin{array}{c}63.6 \\
\pm 5.23\end{array}$ & $\begin{array}{c}107.0 * * \\
\pm 8.09\end{array}$ & $\begin{array}{l}223.7 \\
\pm 9.43\end{array}$ & $\begin{array}{c}290.24 * * \\
4.28\end{array}$ & $\begin{array}{c}5.10 \\
\pm 0.35\end{array}$ & $\begin{array}{l}2.91^{*} \\
\pm 0.10\end{array}$ \\
\hline & 6 & $\begin{array}{l}128.7 \\
\pm 6.92\end{array}$ & $\begin{array}{c}157.79 * * \\
\pm 4.14\end{array}$ & $\begin{array}{c}69.6 \\
\pm 3.62\end{array}$ & $\begin{array}{c}102.16^{* *} \\
\pm 4.54\end{array}$ & $\begin{array}{l}197.0 \\
\pm 8.09\end{array}$ & $\begin{array}{c}289.0 * * \\
2 \pm 1.0\end{array}$ & $\begin{array}{c}5.10 \\
\pm 0.35\end{array}$ & $\begin{array}{l}2.97^{*} \\
\pm 0.13\end{array}$ \\
\hline \multirow[t]{2}{*}{5} & 7 & $\begin{array}{c}134.9 \\
\pm 8.6\end{array}$ & $\begin{array}{c}137.70 \\
\pm 5.90\end{array}$ & $\begin{array}{c}60.2 \\
\pm 3.25\end{array}$ & $\begin{array}{c}102.27 * * \\
\pm 3.62\end{array}$ & $\begin{array}{c}208.90 \\
\pm 8.52\end{array}$ & $\begin{array}{c}258.5 * * \\
4: 3.6\end{array}$ & $\begin{array}{c}4.95 \\
\pm 0.39\end{array}$ & $\begin{array}{l}3.96^{*} \\
\pm 0.24\end{array}$ \\
\hline & 8 & $\begin{array}{c}143.4 \\
\pm 1.06\end{array}$ & $\begin{array}{l}145.60 \\
\pm 2.09\end{array}$ & $\begin{array}{l}70.55 \\
\pm 2.47\end{array}$ & $\begin{array}{c}107.80 * * \\
\pm 4.14\end{array}$ & $\begin{array}{l}203.0 \\
\pm 6.82\end{array}$ & $\begin{array}{c}301.7 * * \\
\pm 8.4\end{array}$ & $\begin{array}{c}4.55 \\
\pm 0.31\end{array}$ & $\begin{array}{l}3.99 * \\
\pm 0.24\end{array}$ \\
\hline
\end{tabular}

*Significant at $\mathrm{P} \leq 0.05$

\section{DISCSUSSION}

Leg problems are reported frequently in broiler flocks, especially in poultry strains that grow fast and have heavy body weight, causing significant and increasing losses. The etiology and pathogenesis of the leg problems appear to be tied to various causes including inadequate mineral and vitamin nutrition, improper management, an optimum lighting and temperature program and some infectious diseases which give rise to the different degrees of leg disorders (Ivan, 2012).

The clinical examination of affected chicks showed bowing or bending of the legs. The birds are reluctant to move and when forced to walk have a stiff gait. Other birds walked on the posterior surface of the hock, in some cases, the tibia is twisted extended laterally. It was uni or bilateral. Some birds suffered from perosis (Slipped of tendon), which is characterized by retarded growth of long bones, widening of the tibiometatarsal joint, twisting or bending of the distal end of tibia and the proximal end of metatarsus and finally, slipping of the gastrocnemius muscle tendon from its condyles. Clinically, it is manifested by impaired locomotion because of leg lateral and posterior malposition of the leg. Such clinical signs were also reported by (Lotta, 2006; Dinev, 2009 and 2012).
**Significant at $\mathrm{P} \leq 0.01$

At post mortem, tibia of some birds showed an abnormal mass of retained cartilage in the proximal metaphysis of the tibiotarsus similar finding was reported by Halit et al. (2012) who stated that, tibial dyschondroplasia is a condition where the cartilage below the growth plate continues to persist instead of calcifying. The condition is seen in long bones and particularly evident in faster growing chickens. Due to lack of adequate calcification the bone at its extremities remains soft and often bends under pressure or heavy body weight. Other birds showed complete slippage of gastrocnemius tendon from its condyles as described by (Julian, 1998). Moreover, some birds had brittle bone of legs which is easily broken where, Adamu et al. (2012) reported that, Calcium $(\mathrm{Ca})$ and Phosphorus $(\mathrm{P})$ are known for their ability to interact with each other. The two minerals are so much dietary essential that deficiency of $\mathrm{Ca}$, for instance, leads to development of rickets, tibial dyschondroplasia (TD), increased chick's mortality and reduced body weight in older birds. Inadequacy of $\mathrm{P}$ also results in similar anomalies and includes loss of skeletal integrity, loss of appetite subnormal growth in young birds and weight loss in older birds.

Calcium and phosphorus are the two most abundant minerals in bone constituting approximately 370 and $170 \mathrm{~g} / \mathrm{kg}$ bone ash, respectively. Bone is a highly complex structure, and the composition varies according to the age and the nutritional status of the birds. As the skeleton is not a stable unit in the 
chemical sense, the exchange of calcium and phosphorus between bones and soft tissue is a continuous process. The balance between these nutrients is important, since an abnormal ratio may be as harmful as a deficiency of either element in the diet (Lotta, 2006). Calcium and Phosphorus together play important roles in most metabolic processes, especially those related to bone formation. The skeleton of birds contains approximately $99 \%$ of the $\mathrm{Ca}$ and $80 \%$ of the $\mathrm{P}$ body reserves (Suttle, 2010). Only a small percentage of the total body concentration of these minerals is found in the blood, but their presence in extracellular fluids is essential (Ansar et al., 2004). It is well accepted that calcium absorption takes place principally in duodenum and the proximal part of the small intestine while phosphorus is absorbed mainly in the upper half of the small intestine (Wasserman, 2004).

The result showed that, the broiler feed of farm 1 and 2 which received commercial rations containing $1.5 \%$ and $1.32 \%$ calcium at two weeks of age suffered from legs disorders, where the NRC (1994) recommendations the calcium contents are 1.00 , 0.90 , and $0.80 \%$ for the starter ( 0 to $21 \mathrm{~d}$ ), grower ( 21 to $42 \mathrm{~d}$ ), and finisher ( 42 to $56 \mathrm{~d}$ ) feeds, respectively. In the matter of fact, Tamim et al. (2004), Manangi and Coon (2008) stated that if young chicks under 2 weeks fed diet contain 1 and $1.5 \%$ calcium, respectively, the $\mathrm{PH}$ of the small intestine will increased up to 6.5 where insoluble calcium and phosphorus formed and forms a complex with manganese and therefor is not absorbed. Also Rama Rao et al. (2006) indicated that excess of calcium in the diet reduces the absorption of phosphorus due to the formation of insoluble complexes in the intestinal lumen. In the same context, (Li et al., 2005) reported that excess dietary calcium might reduce the solubility of inorganic $\mathrm{Mn}$ in digestive tract, thereby lowering tissue $\mathrm{Mn}$ uptake which is cleared confirmed by serum Mn values in this study. Moreover, excess $\mathrm{Ca}$ impedes the availability of other minerals like $\mathrm{P}, \mathrm{Mg}, \mathrm{Mn}, \mathrm{Zn}$ and through the formation of Ca-phytate complexes, reduces the efficacy of phytase. Furthermore, excess dietary $\mathrm{Ca}$ concentration may reduce the energy value of the diet through the chelation of lipids, Therefore, balanced ratio between $\mathrm{Ca}$ and $\mathrm{P}$ is required (Selle et al., 2009).

On the other hand the circumstances of the poultry intestine is almost acidic than alkaline (Bronner, 1987), and in this case high levels of Ca might increase the intestinal $\mathrm{pH}$ and consequently impaired the digestion (Kheiri and Rahmani, 2006).

Leg abnormalities appeared in birds at 3,4 and 5 weeks of age, which correlated to their received commercial ration imbalanced in $\mathrm{Ca}: \mathrm{P}$ ratio which were $(0.84: 1),(1.2: 1),(1.1: 1),(0.97: 1),(1.5: 1)$ and $(0.85: 1)$ respectively. This suggestion agreed with Wang et al. (2013) who found that high dietary calcium or phosphorus and wide $\mathrm{Ca}: \mathrm{P}$ ratios may cause a secondary manganese $(\mathrm{Mn})$ deficiency leading to perosis. While the normal levels of $\mathrm{Ca}: \mathrm{P}$ ratio in broiler ration as recommended by $\mathrm{NRC}$ (National Research council 1994) was (1.67:1). Also Ansar et al. (2004) reported that even any small deviation from optimal supply of $\mathrm{Ca}$ and $\mathrm{P}$ in the diet may produce changes in their serum levels.

Tibial dyschondroplasia (TD) which results in bone deformity and lameness is a disease that affects fast growing birds worldwide (Edwards, 2000). Many factors, such as the calcium/phosphorus ratio and acid-base balance of the diet involve in the development of this condition (Kestin, 2001).

Feed sample contained relatively lower amounts of CP (crude protein) (16.63,16.98,15.69,15,15,15, $14,75,14,69$ and $13.3 \%$ ) which were lower than the desired level $(23 \%, 20 \%$ and $18 \%)$ requirement for starter, grower and finsher respectively recommended by National Research Council's (NRC, 1994).

Manganese acts as a catalyst and cofactor in many enzymatic processes involved in the synthesis of fatty acids and cholesterol, mucopolysaccharide synthesis that surround and protect cells and lubricate joints, in bones, collagen, and connective tissue, and in the synthesis of glycoproteins. Manganese activates the enzymes known as glycolsyl transerferases and xylosyl transferases, which are important in the formation of bone. It has also been theorized that manganese is involved in the production of the thyroid hormone known as thyroxine and in maintaining the health of nerve tissue, essential for maintaining good blood sugar level and cholesterol level (Saric and Lucchini, 2007).

The results of ration analysis showed that decrease of Mn content in ration under 3 weeks of age than their requirement where, the $\mathrm{Mn}$ requirement for broilers during the first $3 \mathrm{wk}$ of life is $60 \mathrm{mg} / \mathrm{kg}$ (National Research Council, 1994). While (Lu et al., 2007) found that addition of $120 \mathrm{mg}$ of $\mathrm{Mn}$ from $\mathrm{MnSO} 4 / \mathrm{kg}$ to basal diet is adequate for decreasing the abdominal fat deposition and improving oxidative stability of bone and meat in broilers.

Although Mn contents were 80 and 100 ppm in farm 1 and 8 respectively, their serum level were decrease significantly $(\mathrm{P} \leq 0.01)$ which may be referred to reduction in its bioavailability as a result of excess dietary calcium or imbalance. Also (Greger, 1998) reported that, manganese is absorbed in the small intestine, but its absorptive efficiency is poor, that estimated $6 \%$ of ingested manganese and very quickly secreted (within minutes) into the gut in bile, that mean low absorption and rapid elimination.

Blood analyses have been performed much less often in avian medicine in comparison to its routine use in 
large animal practices in veterinary medicine. Serum biochemical parameters may provide valuable information for differential diagnosis of nutritional disorders (Quintavalla et al., 2001).

Concerning, the serum calcium concentration in affected birds at two weeks of age which was significantly higher $(\mathrm{P} \leq 0.01)$ than serum concentration (hypercalcemia) in apparently healthy ones, this may be due to an increase in calcium content $(1.5 \%$ and $1.32 \%)$ in their ration. This finding is in agreement to those of Ansar et al. (2004), who observed higher serum calcium concentrations in birds fed high dietary calcium: phosphorus ratios. Also Dalmagro, (2102) found that higher $\mathrm{Ca}$ intake leads to an initial increase in plasmatic Ca levels, which suppresses parathyroid hormone $(\mathrm{PTH})$ secretion, and consequently reduces the production of calcitriol, reducing $\mathrm{Ca}$ and $\mathrm{P}$ absorption in the intestines. The effects of calcitriol on bones are dependent on blood $\mathrm{Ca}$ and $\mathrm{P}$ levels. In individuals with normal plasma $\mathrm{Ca}$ levels, calcitriol stimulates bone formation. Another hormone, calcitonin, has hypocalcemic and hypophosphatemic effects by limiting bone resorption when plasma levels of $\mathrm{Ca}$ are high. Moreover, (Khan and Scott, 2013) reported that feeding a diet deficient or imbalanced in calcium, phosphorus, or vitamin $\mathrm{D}_{3}$ can exhibit lameness at around 10-14 days of age. Meanwhile, serum calcium concentration in affected chicks at 3,4 and 5 weeks of age were lower than the concentration in apparently healthy chicks (hypocalcimeia). This clearly explained where, it accompanied by increase phosphorus content in their ration which strongly correlate to the results of the present study and coincided with that reported by Fernandes et al. (1999) who showed that plasma Ca levels were reduced by increased levels of Phosphorous supplementation.

Regarding, the serum inorganic phosphorus concentration in affected chicks was decreased (hypophosphatemia) than apparently healthy ones. This may be due to there is no relationship between the inorganic phosphorus in serum and the ingested phosphorus, where the inorganic phosphorus is under kidney control which stimulated by parathyroid hormone to excrete phosphate (Xian et al., 2013). In the same context, Moe and Sprague, (2008) reported that when serum phosphorus levels decrease, there is a stimulation of the 1-alpha hydroxylase enzyme in the kidneys, thereby increasing conversion of calcidiol to calcitriol which in turn increases intestinal phosphorus absorption.

The decrease in serum manganese concentration were highly significant $(\mathrm{P} \leq 0.01)$ at $2,3,4$ and 5 weeks of age the concentration was $(2.34,2.43,2.04$, $1.59 \mathrm{ug} / \mathrm{dl}$ ) respectively while the concentration in apparently healthy birds was $(12.13,11-55,10.99$, $11.55 \mathrm{ug} / \mathrm{dl}$ ) at 2,3 and 4 weeks of age respectively.
Result, were in agreement with that recorded by Suttle, (2010) who stated that manganese deficiency in chicks, poults and duckling is manifested by leg problem in the form of perosis or slipped tendon. Also Strause and Saltman, (1987) found that serum concentration of $\mathrm{Mn}$ have been reported to be low in suspected cases of Mn deficiency. Wang et al. (2013) reported that the leg abnormality called hock disease, slipped tendon or perosis was found to be related to manganese deficiency. Manganese was the first nutrient found required for prevention of perosis, manganese is the only one which has an established link between effects of its deficiency. On the other hand Mn may be found in ration in its optimal level but unavailable to be absorbed as affected by other nutrients such as calcium and phosphorous contents.

Serum zinc concentrations were significantly decreased in affected chicks at all ages such results agreed with Khan and Scott (2013) who reported that zinc deficiency symptoms in poultry include slow growth, shortening and thickening of the long bones "hock enlargement". Also Forrest (2012) reported that poults are more likely to show enlarged hock and poor feathering of zinc deficiency.

Regarding, Serum copper concentration was decreased in affected chicks at 2 an 3 weeks of ages this finding agreed with Viguet et al. (2006) who reported that copper deficiency decrease cross linking in bone collagen and increase bone fragility. Orth and Cook (1994) found that many conditions have been found to induce leg abnormalities (tibial dyschondroplasia) including copper deficiency and metabolic acidosis.

Dealing with serum protein levels, the results showed that significantly decrease in the affected birds than apparently healthy ones. $(\mathrm{p} \leq 0.05)$ which may be referred to deficient in protein supplements which strongly observed in ration analysis in this study. Also a positive linear relationship was found between total calcium and total protein in the serum. The amount of total calcium varies with the level of serum protein to which calcium is bound (Calciumbinding proteins) Dreyer, (2011).

Cholesterol is the precursor of the five major classes of steroid hormones: progestagens, glucocorticoids, mineralocorticoids, androgens, and estrogens, also is the precursor of vitamin $\mathrm{D}$, which plays an essential role in the control of calcium and phosphorus metabolism. 7-Dehydrocholesterol (provitamin D3) which is photolysis by the ultraviolet light of sunlight to vitamin D (Berg et al., 2002).

Concerning with, the serum triglyceride and cholesterol levels of the leg affected birds in 3,4 and 5 weeks of age there were significant increase than those of the healthy broilers $(\mathrm{P}<0.01)$. These results agreed with Halit et al. (2012) who found that serum triglyceride and cholesterol rates of birds suffering 
from TD being higher than those of healthy which demonstrated the effect of lipids on leg health. Meanwhile, Ulku et al. (2009) reported that increased serum cholesterol level and decreased thigh meat is considered the main cause of leg weakness. In the same context, serum triglyceride and cholesterol level at 2 weeks of age were not significantly different which may owing to increase of calcium in their ration and serum. This may be true where, excess dietary $\mathrm{Ca}$ concentration may reduce the energy value of the diet through the chelation of lipids as reported by (Selle et al., 2009). Also Adamu et al. (2012) found that higher Ca: P ratios did not favour higher fat deposition. Saric and Lucchini, (2007) reported that Manganese is involved, in glucose metabolism where, the enzyme pyruvate carboxylase, which is utilized in gluconeogenesis, contains tightly bound manganese. While, low levels of manganese reduce insulin production and impair glucose metabolism. There was a nonenzymatic crosslinking of glucose to proteins have been shown to be present in many connective tissues and are also present in bone (Sell and Monnier, 1989), where Sara et al. (1996) reported that glucose and other reducing sugars react with proteins by a non-enzymatic, post-translational modification process called non-enzymatic glycosylation or glycation.

Serum glucose level was increased significantly in affected chickens than apparently healthy birds, such finding could be explained by Klandorf et al. (1995) who suggest that concentrations of plasma glucose in chickens may, in fact, be exerting long-term detrimental effects on tissue proteins, which can be ameliorated by factors that limit the cross-linking reaction and elevated plasma glucose concentrations in chickens $(200-250 \mathrm{mg} / \mathrm{dl})$ can result in the nonenzymatic attachment of glucose to serum proteins. Also Richards et al. (2010) reported that, collagen is the main structural protein of the various connective tissues in animals. Collagen crosslinks have been shown to be important in the increase of bone mechanical strength. The tibias from 5-wk-old chicks were strong but brittle because of low collagen crosslinks and high mineral content.

It could be concluded that, metabolic and management factors are involved in conditions of leg disorders in broilers. Deprivation in feed intake due to birds immobility, suboptimal nutrition, feed ingredients quality, consumption and absorption moreover decrease bioavailability of some element specially manganese and wide calcium: phosphorous ratios and/or imbalance as a result of most of individual farm formulated the ration by themselves which consequently, could lead to errors in their formulation and mixing of the nutrients which not meet the particular requirements of chickens. Rations had positive effect on certain serum biochemical parameters of broiler chickens. So, there is a continuous need to further increase the knowledge of how to optimize commercial broiler production feed for health and welfare, while maintaining production economics.

\section{REFERENCES}

Adamu, S.B.; Geidam, Y.A.; Mohammed, G.; Gambo, H.I. and Raji, A.O. (2012): The influence of varying calcium-phosphorus ratios on finishing and carcass characteristics of broiler finisher chickens under a semi arid environment. ARPN Journal of Agricultural and Biological Science vol. 7, no. 7.

Ansar, M.; Khan, S.A.; Chaudhary, Z.I.; Mian, N.A.; Tipu, M.Y. and Rai, M. F. (2004): Effects of high dietary calcium and low phosphorus on urinary system of broiler chicks.Pakistan Vet. J. 24:113-116.

AOAC (1990): Methods of Analysis of the Association of Official Analytical Chemists, 15th Ed., Association of Official Analytical Chemists, Washington, DC.

Berg, J.M.; Tymoczko, J.L. and Stryer, L. (2002): Biochemistry. 5th edition. Chapter 26-The Biosynthesis of Membrane Lipids and Steroids .Section 26.4Important Derivatives of Cholesterol Include Bile Salts and Steroid Hormones. 1041-1082- New York.

Bronner, F. (1987): Intestinal calcium absorption mechanism and application. J. Nutr., 117: 1347-1352.

Dalmagro, M.R. (2012): The Effects of Dietary Calcium and Phosphorus Levels on Performance, Mineral Retention, Bone Characteristics, Leg Abnormalities, and Walking Ability of Heritage Broilers. A thesis submitted to the Graduate Faculty of North Carolina State University Poultry Science / Nutrition.

Dinev, I. (2012): Clinical and morphological investigations on the incidence of forms of rickets and their association with other pathological states in broiler chickensResearch in Veterinary Science 92 273-277.

Dinev, I. (2009): Clinical and morphological investigations on the prevalence of lameness, associated with femoral head necroses in broiler chickens. British Poultry Science 3, 284-290.

Dreyer, M.J. (2011): Serum total calcium, ionised calcium and corrected total calcium concentrations in kwashiorkor and nephrotic syndrome patients. Medical Technology SA. Volume 25 No. 2 (29-32).

Edwards, H.M. (2000): Nutrition and skeletal problems in poultry. Poultry Science, 79:1018-1023.

Fernandes, J.I.M.; Lima, F.R.; Mendonca, C.X.; Mabe, I.Jr.; Albuquerque, R. and Leal, P.M. 
(1999): Relative bioavailability of phosphorus in feed and agricultural phosphates for poultry. Poultry Sci. 78:1729-1736.

Forrest, H.N. (2012): History of Zinc in Agriculture Adv Nutr. 2012 November; 3(6): 783-789.

Greger, J.L. (1998): Dietary standards for manganese: overlap between nutritional and toxicological studies. J Nutr.128:368S-371S.

Halit, I.; Kübra, A.T.; Recep, G.; Samet, K. and Ali, $K$. (2012): The effect of tibial dyschondroplasia on metabolic parameters in broiler chickens. Ankara Üniv Vet. Fak. Derg, 59, 271-277.

Henry, R.J. (1964): Colorimetric determination of total protein. Clinical Chemistry. Harper and Row Publ., New York, USA, In.

Ivan, D. (2012): Leg Weakness Pathology in Broiler Chickens. J. Poult. Sci., 49: 63-67.

Julian, R.J. (1998): Valgus-Varus Deformity of the Intertarsal Joint in Broiler Chickens Can Vet J.; 25: 254-258.

Kestin, S.C.; Gordon, S., Su, G. and Sorensen, P. (2001): Relationships in broiler chickens between lameness, live weight, growth rate and age. Vet. Rec. 148, 195-197.

Khan, C.M. and Scott, L. (2013): Merck veterinary manual 10th edition. ISBN: 978-0-911910-933.

Kheiri, F. and Rahmani, H.R. (2006): The Effect of Reducing Calcium and Phosphorous on Broiler Performance. International Journal of Poultry Science 5 (1): 22-25.

Klandorf, H.; Holt, S.B.; McGowan, J.A.; Pinchasov, Y.; Deyette, D. and Peterson, R.A.(1995): Hyperglycemia and nonenzymatic glycation of serum and tissue proteins in chickens. Comp Biochem Physiol C Pharmacol Toxicol Endocrinol. 110(2): 215-20.

Krai, I. and Suchy, P. (2000): Haematological studies in adolescent breeding cocks. Acta Vet. Brno., 69: 189-194.

Kurtoglu, F.; V. Kurtoglu, I.; Celike, T.K. and Nizamlioglu, M. (2005): Effects of dietary boron supplementation on some biochemical parameters, peripheral blood lymphocytes, splenic plasma cells and bone characteristics of broiler chicks given diets with adequate or inadequate cholecalciferol (vitamin D3) content. Br. Poult. Sci., 46: 87-96.

Li, S.F.; Luo, X.G.; Lu, L.; Crenshaw, T.D.; Bu , Y.Q.; Liu , B.; Kuang, X.; Shao, G.Z. and Yu, S.X. (2005): Bioavailability of organic manganese sources in broilers fed high dietary calcium Top of Form. Animal Feed Science and Technology.Volume 123, Part 2 , Pages 703-715, 7 .Bottom of Form.

Lotta, W. (2006): Nutritional factors of importance for optimal leg health in broilers: A
reviewAnimal Feed Science and Technology 126, 291-307.

Lu, L.; Luo, X.G.; Liu, C.; Ji, B. and Yu, S.X. (2007): Effect of manganese supplementation and source on carcass traits, meat quality, and lipid oxidation in broilers. J. Anim. Sci. 85:812822.

Manangi, M.K. and Coon, C.N. (2008): Phytate phosphorus hydrolysis in broilers in response to dietary phytase, calcium, and phosphorus concentrations. Poult Sci. 87(8):1577-86.

Moe, S.M. and Sprague, S. (2008): Mineral Bone Disorders in Chronic Kidney Disease. In: Brenner B, editor. The Kidney. ed 8th. Vol 2. Philadelphia: Saunders. p. 1784.

National Research Council (NRC) (1994): Nutrient Requirement of Poultry. The Nutrient Requirement of Farm animals. $9^{\text {th }}$ Ed. National Academy of Science, Washington, DC, USA.

Orth, M.W. and Cook, M.E. (1994): Avian Tibia1 Dyschondroplasia: A Morphological and Biochemical Review of the Growth Plate Lesion and Its Causes. Vet. Pathol. 31: 403414.

Quintavalla, F.; Bigliardi, E. and Bertoni, P. (2001): Blood biochemical baseline values in the Ostrich (Struthio camelus). Università degli studi di Parma, Annali della Facoltà di Med. Vet, XXI: 61-71.

Rama rao, S.V.; Raju, M.V. and Reddy, M.R. (2006): Interaction between dietary calcium and nonphytate phosphorus levels on growth. bone mineralization and mineral excretion in commercial broilers. Animal Feed Science and Technology, v.131, p.133-148.

Richards, J.D.; Junmei, Z.; Robert, J.H.l.; Cindy, A.A. and Julia, J.D. (2010): Trace Mineral Nutrition in Poultry and Swine. Asian-Aust. J. Anim. Sci. 23(11):1527-1534.

Riddell, C. (1992): Noninfectious skeleton disorders of poultry-an overview. In: Bone biology and skeletal disorders in poultry (Whitehead CC ed.) Poultry Science Symposium. Vol. 23. pp. 119-145. Carfax Publishing Company. Abington.

Robert, H.F. (2008): Nutritional factors affecting poultry bone health. Proceedings of the Nutrition Society, 67, 177-183 Symposium on 'Diet and bone health.

Sara, V.; Xin, Z.; Xini, Z.; Aphrodite, K.; Jürgen, B.; Saul, T.; John, B.; Dilip, W.; David, S.; Ihor, T.; Richard, B.; Anthony, C.; John, E. and Peter, U. (1996): An agent cleaving glucose-derived protein crosslinks in vitro and in vivo. Nature 382, 275-278.

Saric, M. and Lucchini, R. (2007): Manganese. In: Handbook of the toxicology of metals eds Nordberg GF, Fowler BA, Nordberg M, Friberg LT, pub Academic Press, Elsevier, 
London 2007; ISBN 978-0-12-369413-3, pp 645- 674.

Sell, D. and Monnier, V. (1989): Structural elucidation of a senescence crosslink fromhuman extracel lularmatrix: Implication of pentose in the aging process. J. Biol. Chem. 264:21597-21602.

Selle, P.H.; Cowieson, A.J. and Ravindran, V. (2009): Consequences of calcium interaction with Phytate and Phytase for Poultry and Pigs. Livestock Science. 124: 126-141

Strause, L. and Saltman, P. (1987): Role of manganese in bone metabolism. In: Kies C, ed.Nutritional Bioavailability of Manganese. Washington, DC: American Chemical Society. Pp. 46-55.

Suttle, N.F. (2010): The Mineral Nutrition of Livestock (4th edition), CABI, London, United Kingdon.

Tamim, N.; Angel, R. and Christman, M. (2004): Influence of dietary calcium and phytase on phytate phosphorus hydrolysis in broiler chickens Poultry Science 83, 1358-1367.

Ulku, G.S.; Bestami, D.; Mehmet, C.; Ibrahim, H.C. and Muammer, B. (2009): Effects of Enriched
Housing Design on Broiler Performance, Welfare, Chicken Meat Composition and Serum Cholesterol.ACTA VET. BRNO, 78: 67-74.

Viguet, C.S.; Garnero, P. and Delmas, P.D. (2006): The role of collagen in bone strength. Osteoporos Int 17: 319-336.

Wang, Z.; Wang, L.; Wang, Z.; Wang, J. and, Liu Ran (2013): Effects of manganese deficiency on serum hormones and biochemical markers of bone metabolism in chicks. Journal of Bone and Mineral Metabolism Volume 31, Issue 3, pp 285-292.

Wasserman, R.H. (2004): Vitamin D and the Dual Processes of Intestinal Calcium Absorption. The American Society for Nutritional Sciences. vol. 134 no. 11 3137-3139.

Xian, R.; Jiang, Fa, H.; Luo, Ming, R.; Qu, Valentino Bontempo; Shu, G. Wu; Hai, J.; Zhang, Hong, Y. Yue, and Guang, H.Qi (2013): Effects of non-phytate phosphorus levels and phytase sources on growth performance, serum biochemical and tibia parameters of broiler chickens. Italian Journal of Animal Science. volume 12:e60.

\section{دراسة حقلية عن بعض العوامل الغذائية المسببة لمشاكل الارجل فى دجاج التسمين

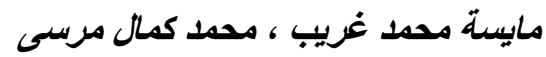 \\ Email: dr-mmg63@yahoo.com}

أجريت هذه الدر اسة الحقلية لتقييم العلاقة بين بعض مكونات العليقة الدقدمة للطيور و المكونات البيوكيميائية للام فى بدارى التسمين

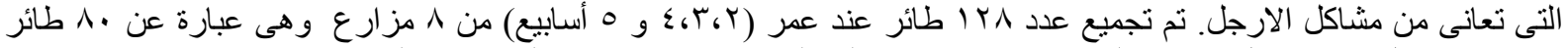

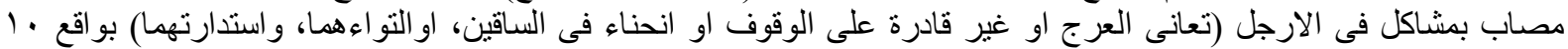

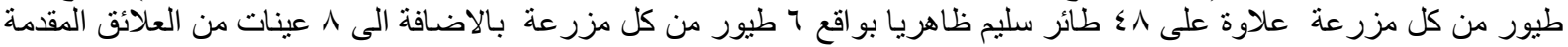

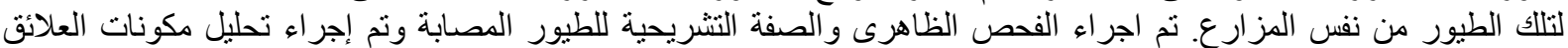

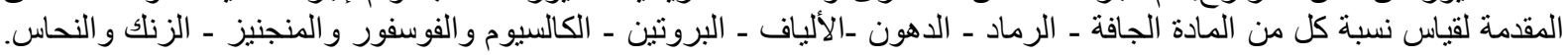

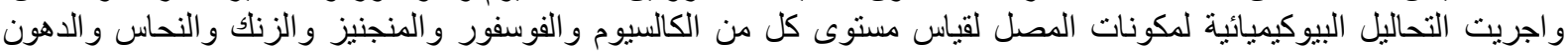

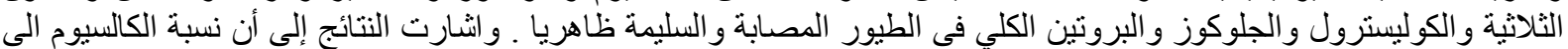

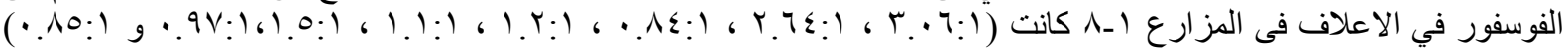

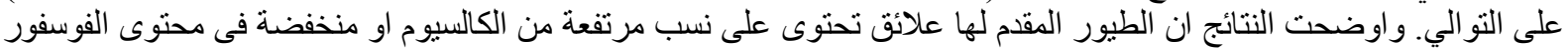

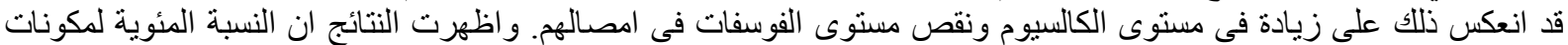

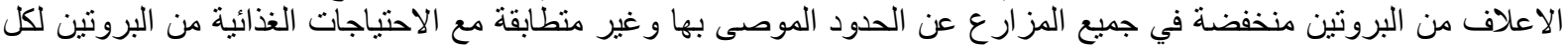

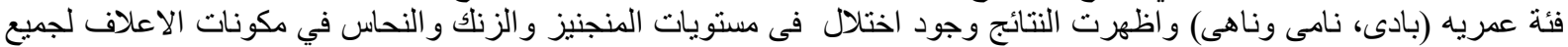

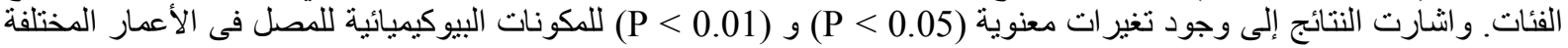

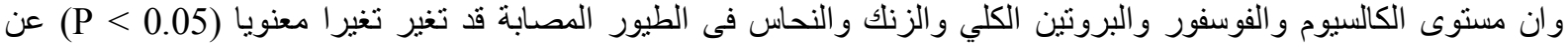

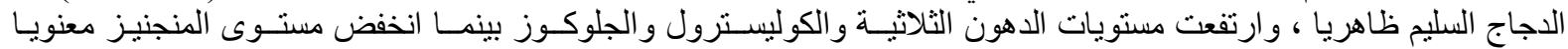
(P >0.01)

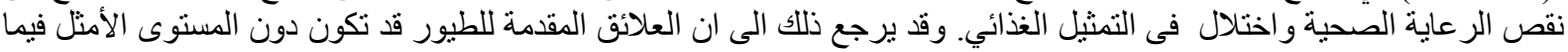

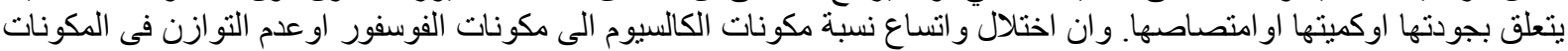

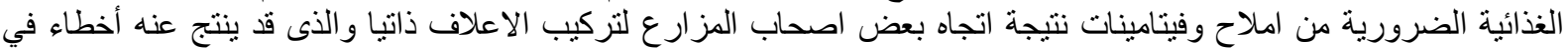

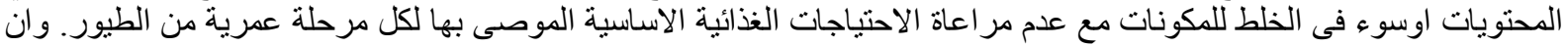

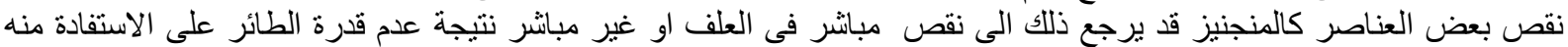

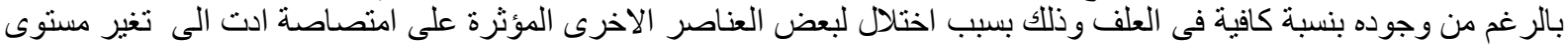

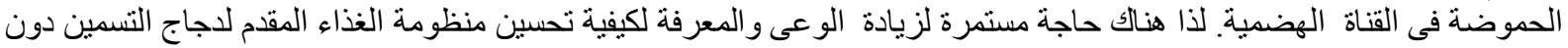
الاخلال بمقومات الصحة و الرعاية مع الحفاظ على القتصاديات الإنتاج. 